\title{
Age Estimation of the Japan Sea on the Basis of Stratigraphy, Basement Depth, and Heat Flow Data
}

\author{
Kensaku TAMAKI ${ }^{1}$ \\ Geological Survey of Japan, Yatabe, Ibaraki, Japan
}

(Received January 14, 1986)

\begin{abstract}
Ages of the Japan and the Yamato Basins in the Japan Sea were examined on the basis of three independent methods; stratigraphic consideration of the basin sediments, age-depth correlation, and age-heat flow correlation. Basement depths of the Japan and the Yamato Basins after sediment loading correction were compared with those of other marginal seas in the Western Pacific whose ages are well constrained. The age estimations by age-depth correlation and age-heat flow correlation show good coincidence in the Japan Basin. The age estimation of the Yamato Basin, however, shows a discrepancy among the three methods; the basement depth shows an age range from $6 \mathrm{Ma}$ to $0 \mathrm{Ma}$, sediment stratigraphy shows that of about $10 \mathrm{Ma}$, and heat flow data show the age from $30 \mathrm{Ma}$ to just over $10 \mathrm{Ma}$. This discrepancy can be explained by the thick accumulation of Neogene volcaniclastics which are represented as acoustic basements on seismic reflection records with a refraction velocity of $3.5 \mathrm{~km} / \mathrm{sec}$. The final estimated age of the Japan and the Yamato Basins is identical with a range of $30 \mathrm{Ma}$ or older to $15 \mathrm{Ma}$ or slightly younger.
\end{abstract}

\section{Introduction}

The age of the Japan Sea has been controversial with estimates ranging from Mesozoic (e.g., GNIBIDENKO, 1979), to Early-Middle Miocene time (e.g., OTOFUJI et al., 1985a), while ages of most of other marginal seas in the Western Pacific have been identified. This ambiguity makes an obstacle for the study of the Cenozoic tectonic evolution of the Japanese islands and the Western Pacific. The age of the Japan Sea will present an important constraint for the tectonic evolution of the Western Pacific.

The age of the ocean floor is obtained by the identification of magnetic anomaly lineations and the age determination of basement rocks by deep sea drilling. Ages of most of the marginal seas in the Western Pacific have been determined by these two methods. Both of these two methods, however, are not successful for the Japan Sea. The magnetic anomaly pattern of the Japan Sea, which is complicated with weak amplitude is difficult to identify (e.g., ISEZAKI and UYEDA, 1973). Four DSDP holes of the Japan Sea did not reach the basement in the basin area (Fig. 1) (KARIG and INGLE, Jr., 1975).

There are some other methods to constrain the age of the ocean floor. Basement depth, heat flow value, and lithospheric thickness are good indicators for this. They have simple correlations with the age of the ocean floor in terms of square root of age

\footnotetext{
${ }^{1}$ Present Address: Ocean Research Institute, University of Tokyo, Tokyo, Japan.
} 


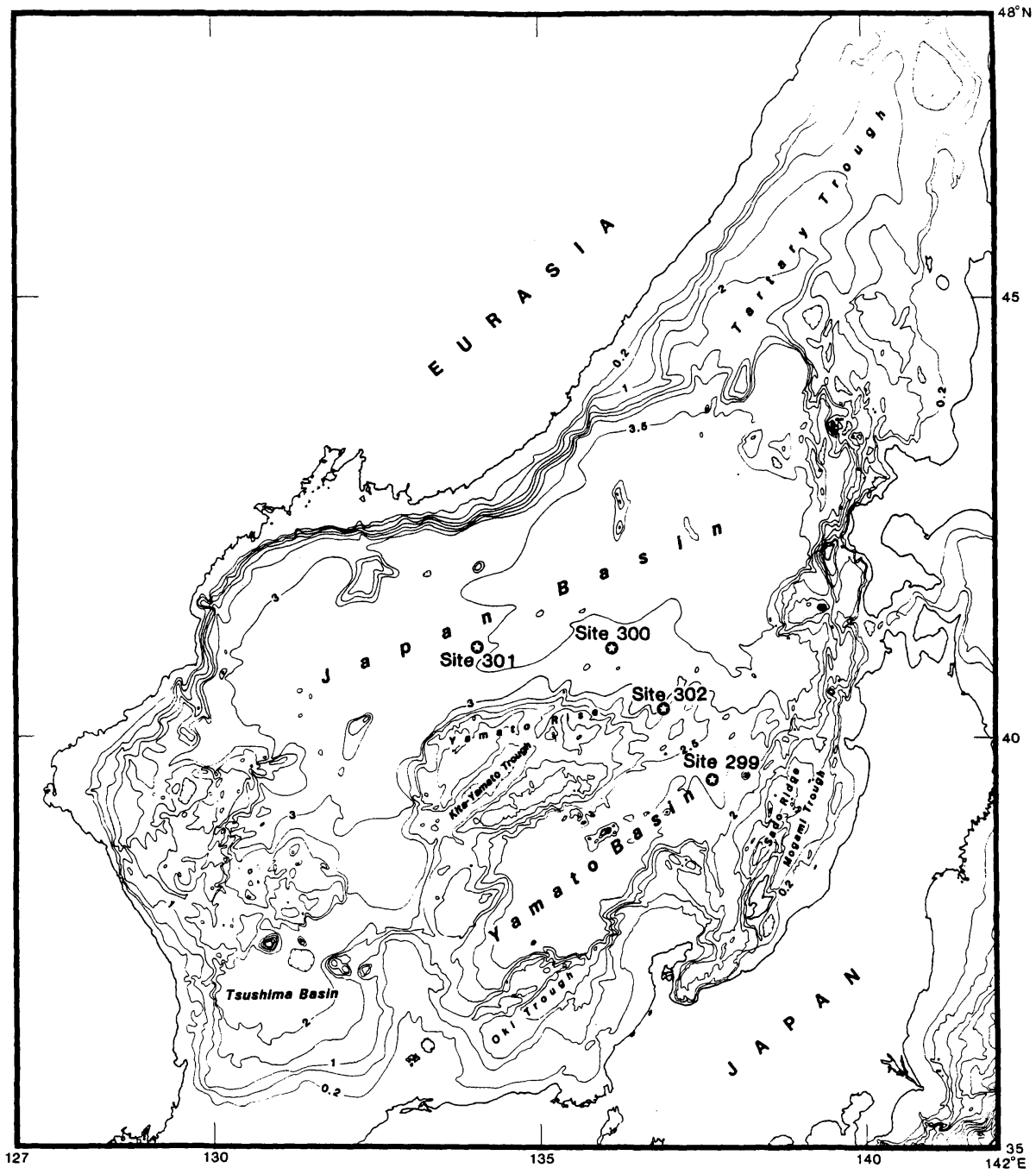

Fig. 1. Topography of the Japan Sea with DSDP Leg 31 sites.

(PARSONS and SClater, 1977; Yoshil et al., 1976). These correlations have been established in such major oceans as the Pacific, Indian, and Atlantic Oceans, but have still been controversial in the marginal sea basins. Such correlation is the result of the cooling effect of the lithosphere according to its age gradient after the formation at the mid-oceanic ridge. In the context of plate tectonics, the formation of the marginal seas is caused by sea floor spreading analogous to the process along mid-oceanic ridges. This suggests the possibility that such correlation is applicable to the marginal sea basins such as the Japan and the Yamato Basins.

Abundant sampling data and DSDP drilling data are available in the Japan Sea. Sediment stratigraphy of the basin area can be deduced from the bottom sampling data, drilling data, and seismic reflection profiles. The age estimation of the bottom of 
the sediments using the stratigraphy well constrains the age of the underlying basement. Thus, the sediment stratigraphy also presents constraints for the formation age of the Japan Sea. In this paper, I discuss and estimate the age of the Japan Sea on the basis of three independent methods; stratigraphic consideration of the basin sediments, age-depth correlation, and age-heat flow correlation.

\section{Age Estimation Based on Sediment Stratigraphy}

There are four major sedimentary basins in the Japan Sea. They are the Japan Basin, the Yamato Basin, the Tartary Trough, and the Tsushima Basin (Fig. 1). The previous seismic refraction surveys document or suggest that these basins are underlain by oceanic or sub-oceanic crusts (e.g., LUDWIG et al., 1975). These basins are buried by the sediments with a maximum thickness of 1.5 to $3.0 \mathrm{sec}$ in two-way acoustic travel time (ISHIWADA et al., 1984). Abundant geological and geophysical data, including deep sea drilling data by DSDP, are available in the Yamato and the Japan Basins (Fig. 2). The sediment stratigraphy is deducible from these abundant data.

Two major stratigraphic units are observed in the Yamato Basin (Fig. 3), a stratified layer in the upper part and a transparent layer in the lower part. Another

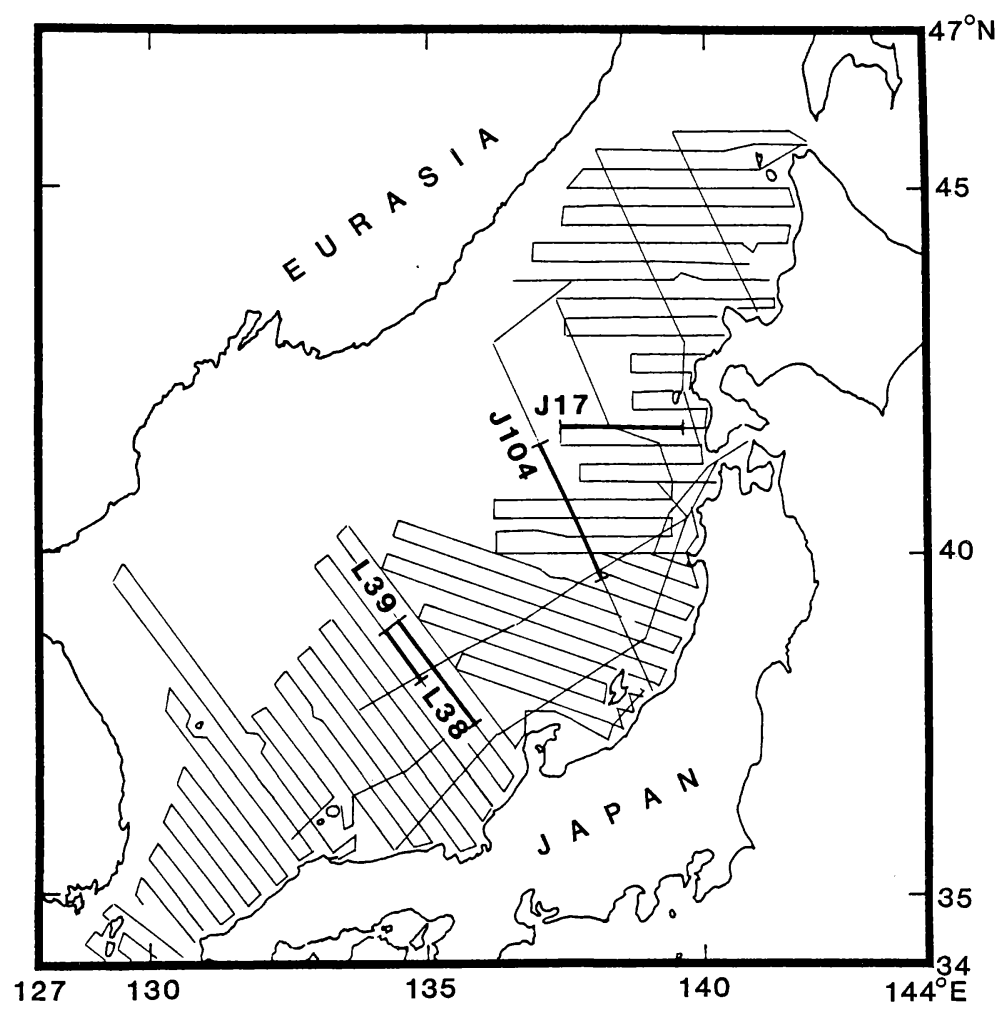

Fig. 2. Survey track lines of Geological Survey of Japan research cruises GH77-2, GH77-3, GH78-2, and GH78-3. Solid lines show localities of seismic profiles of Figs. 3, 4, 6, and 12. 


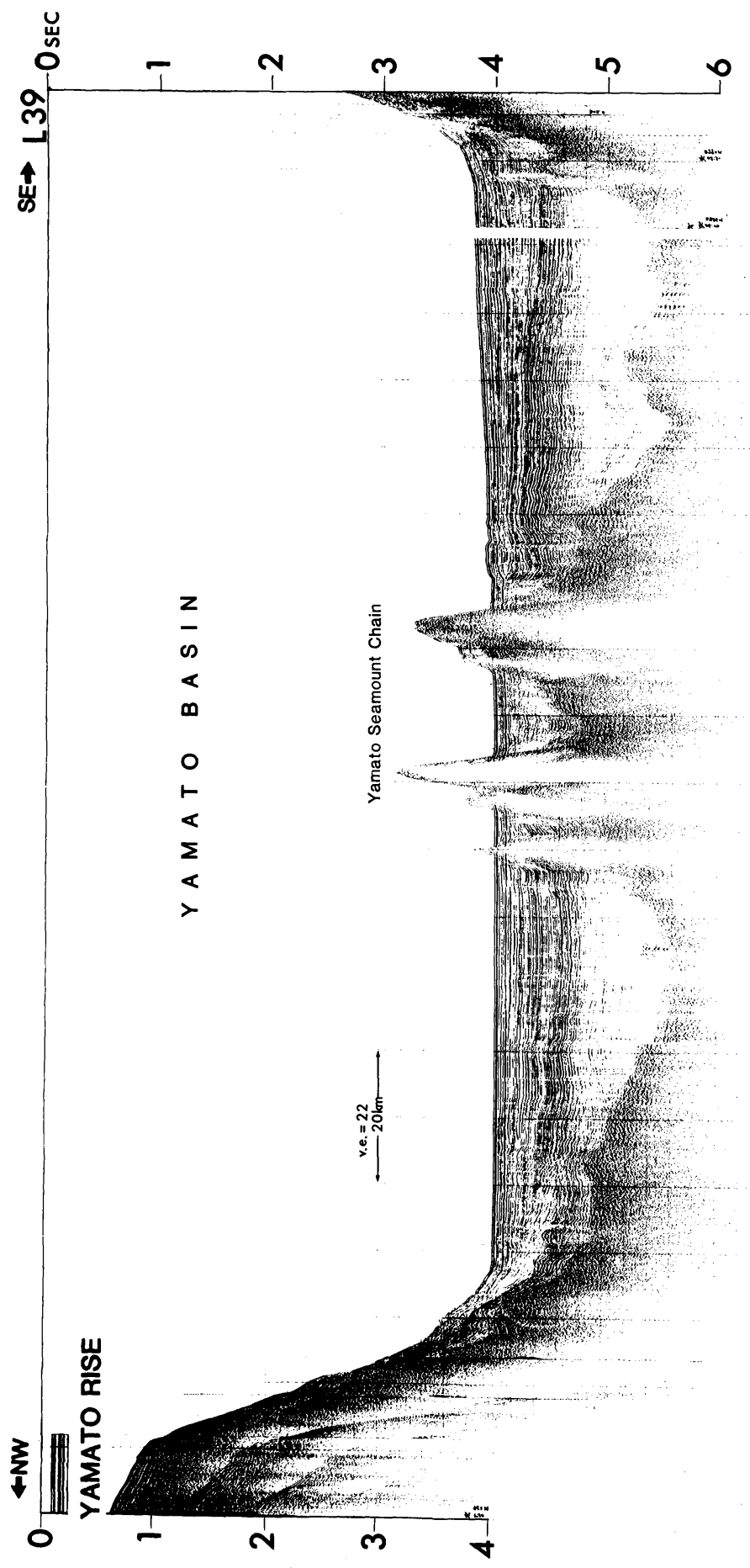

O) 
stratified layer underlies the transparent layer in the marginal area of the basin (Fig. 4). This stratified layer is also underlain by another transparent layer on the flanks of the rise (Fig. 4). Thus, the stratigraphic units on the seismic profiles of the Yamato Basin are divided into four units in descending order; the upper stratified layer, the upper transparent layer, the lower stratified layer, and the lower transparent layer. The lower stratified layer and the lower transparent layer are only observed in the marginal part of the basin and on the flank of the rise.

There are two deep sea drilling sites in the Yamato Basin and its vicinity; Site 299 in the central part of the basin and Site 302 on the northeastern flank of the Yamato Rise (KARIG and INGLE, Jr., 1975). Outcrops of the lower sedimentary units of the Yamato Basin are commonly observed along the surrounding rises and ridges such as the Yamato Rise and the Sado Ridge (TAMAKI et al., 1981). The results of two deep sea drilling sites together with the bottom sampling data from the surrounding outcrops present constraints that are effective for estimating the age of the acoustic basement of the Yamato Basin, even though the hole of Site 299 in the basin did not reach the basement. The principle of the age estimation of the Yamato Basin based on such data is summarized in a schematic drawing as shown in Fig. 5.

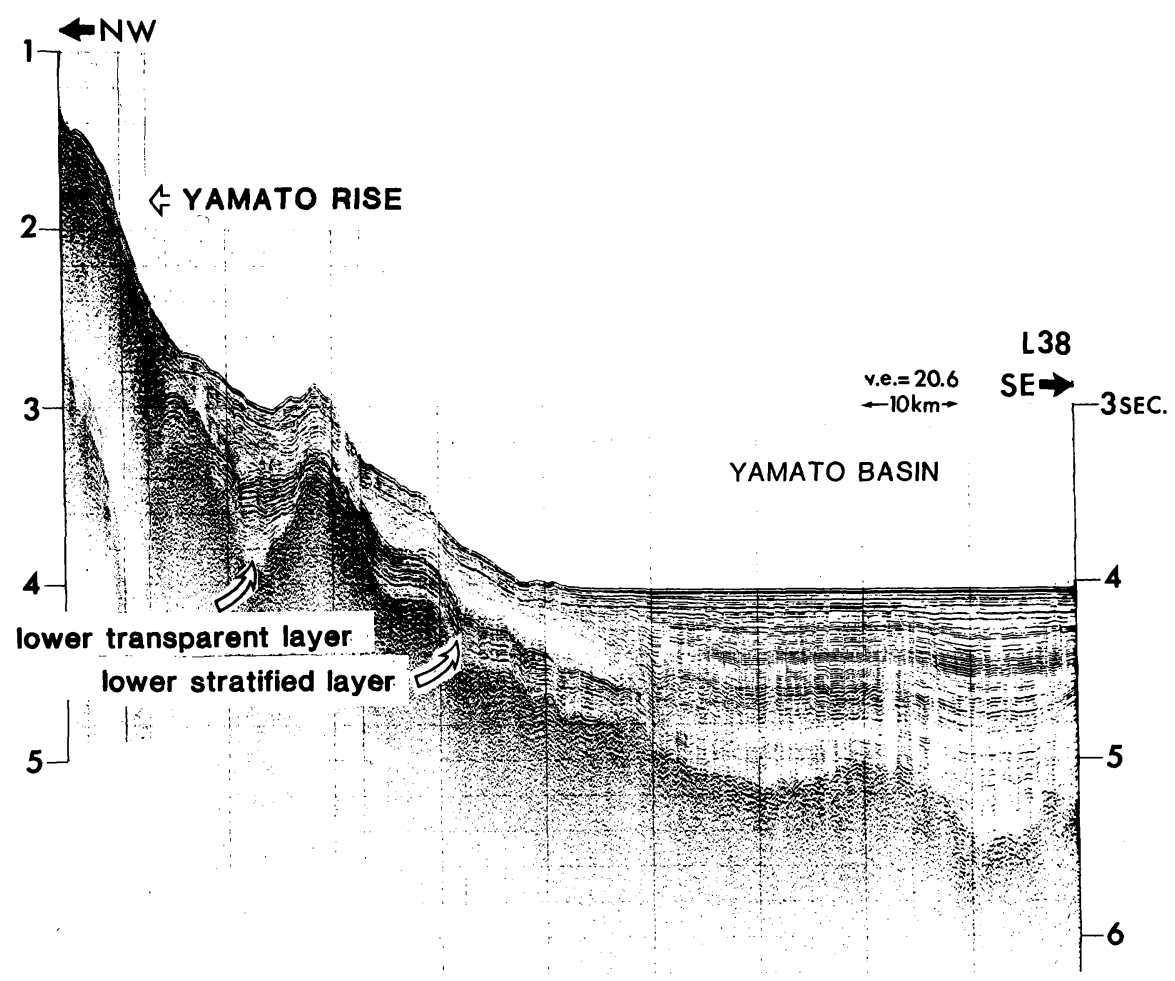

Fig. 4. Seismic profile of the northwestern margin of the Yamato Basin. Line L38 on Fig. 2. 


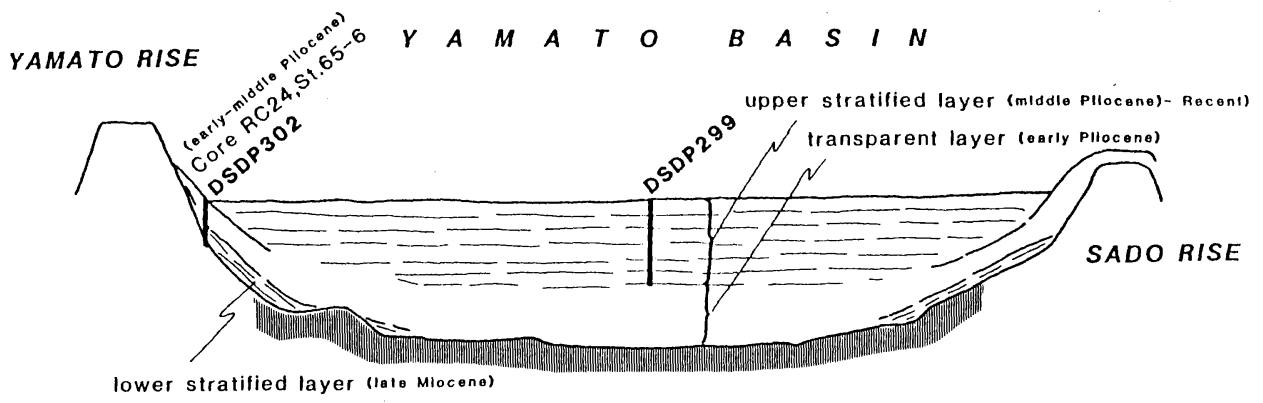

Fig. 5. Summary cartoon of stratigraphy of the Yamato Basin.

The hole of the Site 299 stopped at the bottom of the upper stratified layer and the age of the hole bottom was estimated to be $3.5 \mathrm{Ma}$ by diatom analysis (KoIZUMI, 1979). The upper transparent layer, which was not penetrated by the drilling, crops out on the southern slope of the Yamato Rise. Piston and gravity cores from the southern slope of the Yamato Rise such as sites RC24 and St. 65-6 recovered older sediments with an age of 4 to 5 Ma (HonZA, 1979; KoIZUMI, 1979). Site 302 penetrated the transparent layer and the lower stratified layer on the flank of the Yamato Rise and almost touched the basement. Diatom analysis on this site shows that the age of the lower stratified layer and the lower transparent layer is from 5 to 9 Ma (KolzumI, 1979). The value of $9 \mathrm{Ma}$ is based on the assumption that sedimentation rate is constant. A chip of supposed basement rock was sampled from the bottom of site 302 . Although the age was not determined, it is probably correlated with the Oligocene-Miocene volcanic rocks (so-called "Green Tuff" horizon on the Japanese islands) (SHIMAZU, 1979). According to these results, the age of the lower stratified layer is older than $5 \mathrm{Ma}$, presumably extending to $10 \mathrm{Ma}$.

The lower stratified layer of Late Miocene age ( $5 \mathrm{Ma}$ to $10 \mathrm{Ma}$ ) is not distributed in the central part of the basin, but is distributed only in the marginal area of the Yamato Basin. There is a problem about tracing the lower stratified layer into the central basin area. This layer appears to become transparent towards the central part of the basin. The age of the bottom of the transparent layer at the central part of the basin is estimated to have almost the same age as that of the lower stratified layer at the margin. Consequently, it is estimated that the age of the acoustic basement or the age of the bottom of the sedimentary sequence of the Yamato Basin is around $10 \mathrm{Ma}$ (Middle-Late Miocene time). The acoustic basement of the Yamato Basin, however, may not be correlated to oceanic basement or oceanic basalts as discussed later. The age for the Yamato Basin needs more discussion.

In the case of the Japan Basin, there are no outcrops of the lower sedimentary units in the margin area of the basin. DSDP Site 301 in the Japan Basin presents a unique stratigraphic constraint for the sedimentary sequence of the basin. The sedimentary sequence of the Japan Basin is divided into two units; the stratified layer in the upper part and the transparent layer in its lower part (Fig. 6). The penetration of Site 302 was $497 \mathrm{~m}$, nearly reaching the bottom of the upper stratified layer. The age of the bottom of the hole is estimated to be $4 \mathrm{Ma}$ on the basis of the diatom analysis 


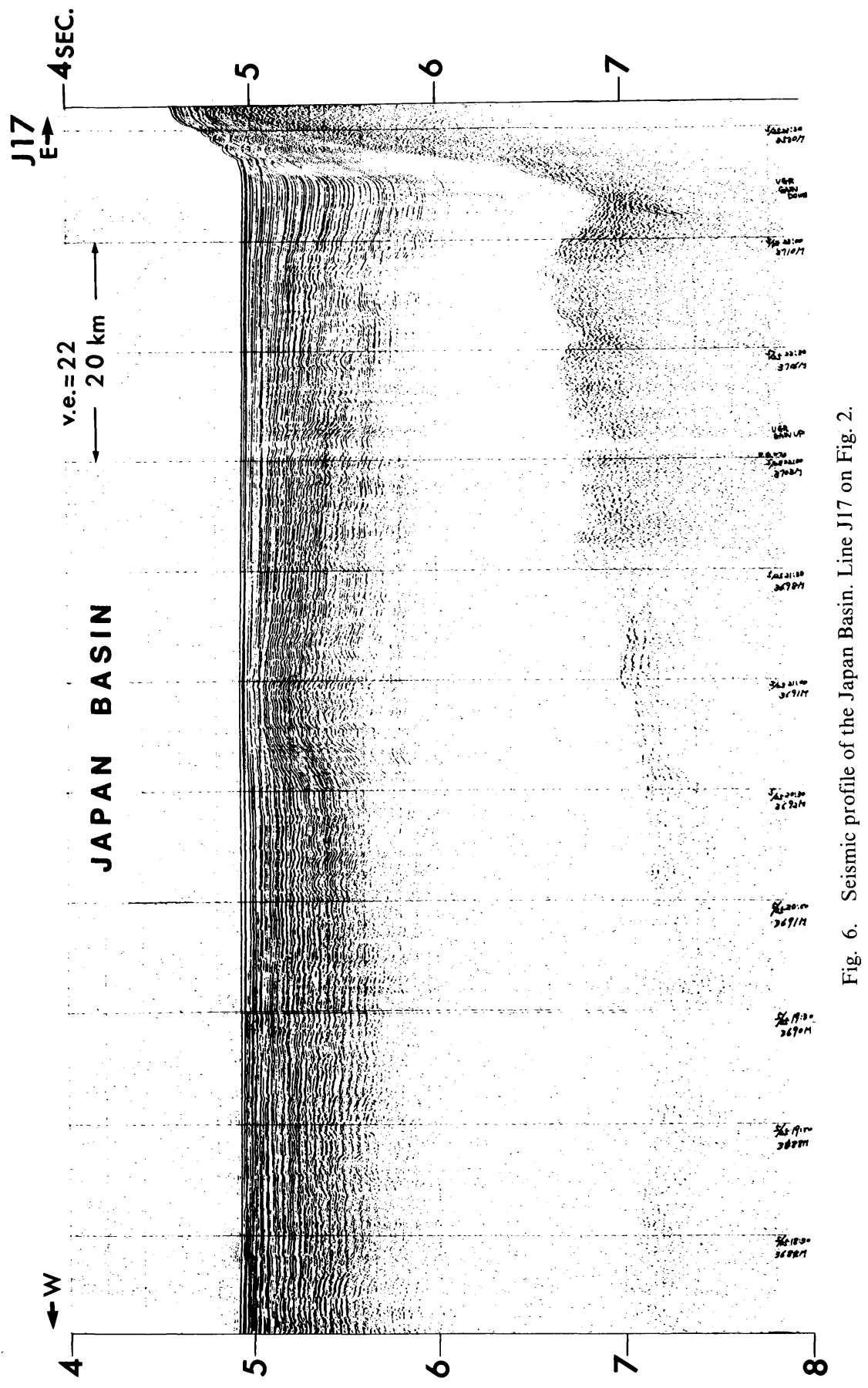


(KolzUMI, 1979). The maximum thickness of the sediments of the Japan Basin is 2.5 seconds in two-way travel time which is considerably thicker than that of the Yamato Basin of 1.5 seconds (ISHIWADA et al., 1984). This difference of the sediment thickness is due to the difference of the thickness of the transparent layer, while the upper stratified layer shows the same thickness and age. The difference of the sediment thickness in both basins indicates that the age of the basement in the Japan Basin is older than that in the Yamato Basin.

\section{Age Estimation Based on Basement Depth}

Table 1 shows the correlation of lithospheric thickness, depth, and terrestrial heat flow of the oceanic lithosphere according to its age. This correlation was established in the major oceans, the Pacific, the Indian, and the Atlantic oceans as a function of square root of the age. The basement depth of the oceanic crusts in the marginal sea does not follow this age-depth correlation (SCLATER et al., 1976). KOBAYASHI (1984) compiled the age-depth correlation in the marginal seas and suggested that a similar correlation is observed in the marginal sea but that the depth of the basement in the marginal seas is generally $1000 \mathrm{~m}$ deeper than the calculated depth from the equation for major oceans. The comparison of basement depth of the basins of the Japan Sea with those of the other marginal seas in the Western Pacific whose ages are well identified will present a constraint for the age estimation of the Japan Sea.

A sediment loading correction is necessary in the discussion of the basement depth of the marginal seas which have thick accumulations of sediments. If the sedimentary cover is removed from the basin, the basement of the basin will rebound isostatically. The basement depth of isostatic compensation after removal of the sediments should be used for the discussion of the age. CROUGH (1983) presented a simple formula for the sediment loading correction of an oceanic basin. The correction formula is:

basement depth after sediment loading correction (m)

$=($ water depth $(\mathrm{m}))+600 *($ two-way sediment thickness $(\mathrm{sec}))$.

In the case of the Japan Basin on Fig. 6, the water depth is $3690 \mathrm{~m}$ and the two-way sediment thickness is 2.1 seconds. Then the basement depth after the sediment loading correction is $4950 \mathrm{~m}$ and was obtained as follows.

$$
3690+600 * 2.1=4950(\mathrm{~m})
$$

According to Table 1 the basement depth of $4950 \mathrm{~m}$ corresponds to an age greater than $48 \mathrm{Ma}$. Depth 1 and Depth 2 on the table, however, are only valid for major oceans such as the Pacific and the Atlantic oceans but not for those of marginal seas.

Figure 7 shows a comparison of the age basement depth after sediment loading correction of marginal seas in the Western Pacific. The basement here is identical with the acoustic basement on the seismic profile. The Shikoku Basin, which is documented to have been active from $30 \mathrm{Ma}$ to $15 \mathrm{Ma}$ from the deep sea drilling results and the identification of magnetic anomaly lineations (KLEIN and KOBAYASHI, 
Table 1. Basement depth (Depth 1 and Depth 2), heatflow (Heatflow 1 and Heatflow 2), and lithospheric thickness according to the age of the oceanic crusts.

\begin{tabular}{|c|c|c|c|c|c|}
\hline $\begin{array}{l}\text { Age } \\
(M a)\end{array}$ & $\begin{array}{l}\text { Basement } \\
\text { Depth } 1(\mathrm{~m})\end{array}$ & $\begin{array}{l}\text { Basement } \\
\text { Depth2 (m) }\end{array}$ & $\begin{array}{l}\text { Heatflow1 } \\
(\mathrm{mW} / \mathrm{m} 2)\end{array}$ & $\begin{array}{l}\text { Heatflow2 } \\
(\mathrm{mW} / \mathrm{m} 2)\end{array}$ & $\begin{array}{c}\text { Lithosphere } \\
\text { Thickness }(\mathrm{km})\end{array}$ \\
\hline 5 & 3504 & 3283 & 211 & 224 & 16.75 \\
\hline 6 & 3561 & 3357 & 193 & 205 & 18.35 \\
\hline 7 & 3614 & 3426 & 179 & 190 & 19.82 \\
\hline 8 & 3664 & 3490 & 167 & 177 & 21.18 \\
\hline 9 & 3710 & 3550 & 157 & 167 & 22.47 \\
\hline 10 & 3754 & 3607 & 149 & 159 & 23.69 \\
\hline 11 & 3795 & 3661 & 142 & 151 & 24.84 \\
\hline 12 & 3835 & 3712 & 136 & 145 & 25.95 \\
\hline 13 & 3873 & 3762 & 131 & 139 & 27.01 \\
\hline 14 & 3910 & 3810 & 126 & 134 & 28.03 \\
\hline 15 & 3946 & 3856 & 122 & 130 & 29.01 \\
\hline 16 & 3980 & 3900 & 118 & 125 & 29.96 \\
\hline 17 & 4013 & 3943 & 115 & 122 & 30.88 \\
\hline 18 & 4046 & 3985 & 111 & 118 & 31.78 \\
\hline 19 & 4077 & 4026 & 108 & 115 & 32.65 \\
\hline 20 & 4107 & 4065 & 106 & 112 & 33.50 \\
\hline 21 & 4137 & 4104 & 103 & 109 & 34.32 \\
\hline 22 & 4166 & 4142 & 101 & 107 & 35.13 \\
\hline 23 & 4195 & 4179 & 98 & 105 & 35.92 \\
\hline 24 & 4223 & 4215 & 96 & 102 & 36.69 \\
\hline 25 & 4250 & 4250 & 94 & 100 & 37.45 \\
\hline 26 & 4277 & 4285 & 93 & 98 & 38.19 \\
\hline 27 & 4303 & 4319 & 91 & 97 & 38.92 \\
\hline 28 & 4329 & 4352 & 89 & 95 & 39.63 \\
\hline 29 & 4354 & 4385 & 88 & 93 & 40.33 \\
\hline 30 & 4379 & 4417 & 86 & 92 & 41.02 \\
\hline 31 & 4403 & 4449 & 85 & 90 & 41.70 \\
\hline 32 & 4427 & 4480 & 83 & 89 & 42.37 \\
\hline 33 & 4451 & 4511 & 82 & 87 & 43.03 \\
\hline 34 & 4474 & 4541 & 81 & 86 & 43.67 \\
\hline 35 & 4497 & 4571 & 80 & 85 & 44.31 \\
\hline 36 & 4520 & 4600 & 79 & 84 & 44.94 \\
\hline 37 & 4542 & 4629 & 78 & 82 & 45.56 \\
\hline 38 & 4564 & 4658 & 77 & 81 & 46.17 \\
\hline 39 & 4586 & 4686 & 76 & 80 & 46.78 \\
\hline 40 & 4608 & 4714 & 75 & 79 & 47.37 \\
\hline 41 & 4629 & 4741 & 74 & 78 & 47.96 \\
\hline
\end{tabular}

The equations for the calculation are as follows; Depth $1=2900+270 *(\text { Age })^{1 / 2}$ (HAYES, 1983), Depth

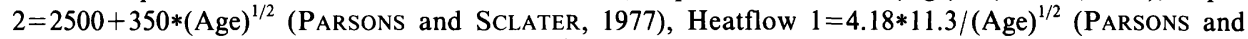
SClATER, 1977), Heatflow $2=4.18 * 12 /(\text { Age })^{1 / 2}\left(\right.$ DAviS and LiSTER, 1977), and Thickness $=7.49 *(\operatorname{Ag~e})^{1 / 2}$ (Yoshil et al. 1976).

1980), has a basement depth of 4500 to $5000 \mathrm{~m}$ after sediment loading correction. The South China Basin in the South China Sea with an age of 30 to $17 \mathrm{Ma}$ also shows the same basement depth range of 4500 to $5000 \mathrm{~m}$. The South China Basin is overlain by thicker sediments, 2.0 seconds, than the Shikoku Basin which has a sediment thickness of less than 0.5 second. The age range and basement depth range after sediment loading correction of the Shikoku Basin and the South China Basin coincide 

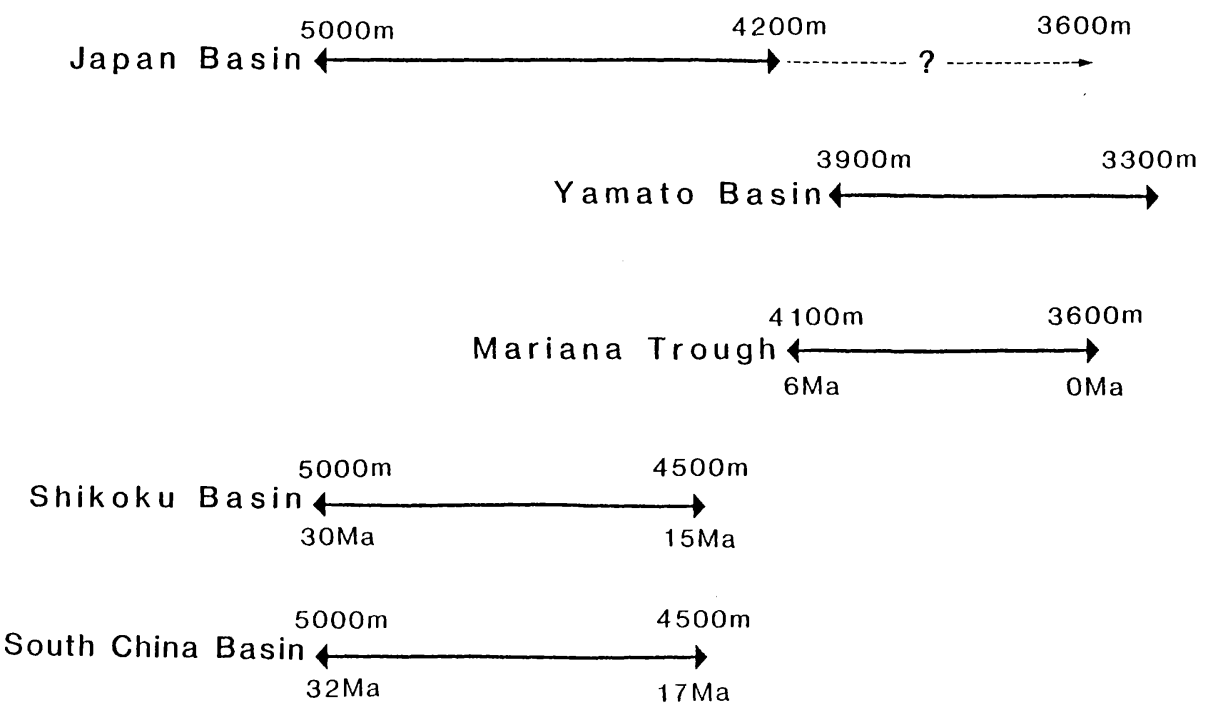

Fig. 7. Basement depths and ages of marginal basins of the Western Pacific. The basement depths are depths of acoustic basements on seismic profiles after sediment loading correction by CROUGH's method (1983). Question marks show marginal shallow basements in the basin and may not be correlated to oceanic crusts. The identified ages of the basins are based on KLEIN and KOBAYASHI (1980) for the Shikoku Basin, TAYlor and HAYES (1983) for the South China Sea, and HuSSONG and UyedA (1982) for the Mariana Trough.

with each other. This means that the comparison method of basement depth after sediment loading correction is valid for the age estimation of the marginal sea basins. Figure 7 also suggests that the basement depth after sediment loading correction is 600 to $700 \mathrm{~m}$ deeper than the calculated depth from the age-depth equation for major oceans. The difference, 600 to $700 \mathrm{~m}$, is less than the previously suggested difference, $1000 \mathrm{~m}$, by KOBAYASHI (1984).

Figure 7 shows that the basement depth of the Japan Basin is almost the same as those of the Shikoku Basin and the South China Basin. The Shikoku Basin has an age range of 30 to $15 \mathrm{Ma}$ and the South China Basin has an age range of 32 to $17 \mathrm{Ma}$. It is probable that the Japan Basin has an age range of about 30 to $15 \mathrm{Ma}$. The basement of the Japan Basin becomes shallower at some margins of the basin and reaches to 3600 $\mathrm{m}$ after sediment loading correction. The depth of $3600 \mathrm{~m}$ is correlated to the age of 0 $\mathrm{Ma}$ on the basis of comparison with the Mariana Trough. The acoustic basement of the Japan Sea, however, commonly has a sonic velocity of $3.5 \mathrm{~km} / \mathrm{sec}$ which is slower than the normal oceanic layer $(4.5-5.5 \mathrm{~km} / \mathrm{sec}$ layer) (LUDwIG et al., 1975). The presence of the $3.5 \mathrm{~km} / \mathrm{sec}$ layer is critical for the discussion of the basement depth. This problem is discussed later.

ABE and KANAMORI (1970a) measured group velocities of surface waves of earthquakes across the Japan Basin and concluded that lithospheric thickness of the Japan Basin is about $30 \mathrm{~km}$. The thickness of $30 \mathrm{~km}$ for the lithosphere corresponds to the age of $17 \mathrm{Ma}$ according to YosHII et al. (1976) (Table 1). This estimation is not 
greatly different from the above estimation, if we take account of the rough resolution of the measurements of lithospheric thickness by surface wave. ABE and KANAMORI (1970b) observed the same value, $30 \mathrm{~km}$, for the lithospheric thickness of the eastern half of the Philippine Sea (Shikoku-Parece Vela Basin) whose age is $32 \mathrm{Ma}$ to $15 \mathrm{Ma}$. The same thickness of the lithosphere of the Japan Basin and the Shikoku Basin supports that the Japan Basin has the comparable age with Shikoku Basin.

The basement depth of the Yamato Basin is shallower than that of the Japan Basin (Fig. 8). The basement depth after sediment loading correction is almost the same as that of the Mariana Trough and the suggested age is 6 to $0 \mathrm{Ma}$. The sonic velocity of the acoustic basement of the Yamato Basin does not show normal oceanic layer either. This problem is also discussed later.

\section{Age Estimation Based on Heat Flow Value}

There have been several discussions about age-heat flow correlation of the marginal sea basins. SCLATER et al. (1976) studied the heat flow value of the

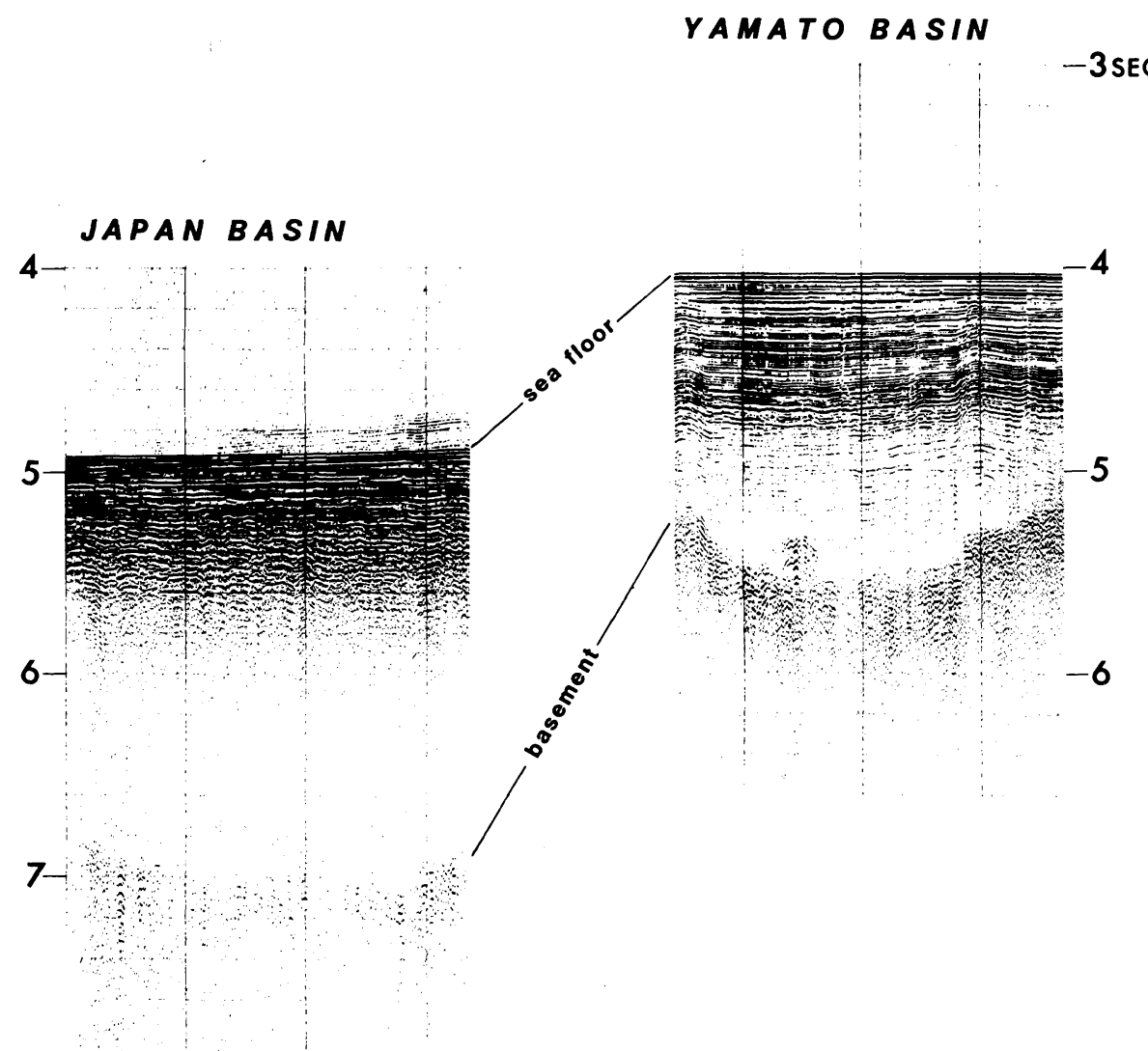

Fig. 8. Typical profiles of the Japan Basin and the Yamato Basin. Both profiles represent the area of the thickest sediments of each basin. 
Philippine Sea and suggested that the age-heat flow equation for the major oceans is applicable to the marginal seas. WATANABE et al. (1977) compiled the heat flow data in the Western Pacific and concluded that the heat flow value of the marginal seas is appreciably higher than the value calculated from age-heat flow equation of the major oceans. KONO and AMANO (1977) examined the age-heat flow correlation of the Japan Sea and presented an opposing conclusion. They evaluated the influence of sedimentation ratio to the heat flow value on the basis of VON HERZEN and UYEDA's (1963) model which takes account of cooling effects by turbidite sedimentation and concluded that the heat flow value of the Japan Sea is lower than the value based on age-heat flow equation when the sedimentation ratio is large with the range from $10^{-3}$ $\mathrm{cm} / \mathrm{yr}$ to $10^{-1} \mathrm{~cm} / \mathrm{yr}$. These divergent observations were caused by the uncertainty of the age of some marginal seas at that time. ANDERSON (1980) later examined the age-heat flow correlation in marginal seas of well identified ages and suggested that the age-heat flow correlation similar to major oceans exists in the marginal seas. TAYLOR and HAYES (1983) measured the heat flow value of the South China Basin and confirmed that the age-heat flow correlation of the major oceans are applicable to the marginal seas (Fig. 9). The South China Basin has a sedimentary cover with the thickness of about 2.0 seconds, which resembles the Japan Sea. Here I examine the heat flow value of the Japan Sea according to the results by ANDERSON (1980) and TAYLOR and HAYES (1983) to show that the age-heat flow correlation of the major oceans is valid even in marginal sea basins.

Table 2 shows selected heat flow values from the digital heat flow data of the Japan Sea (YoSHII and YAMANO, 1983) which include heat flow data from over 100

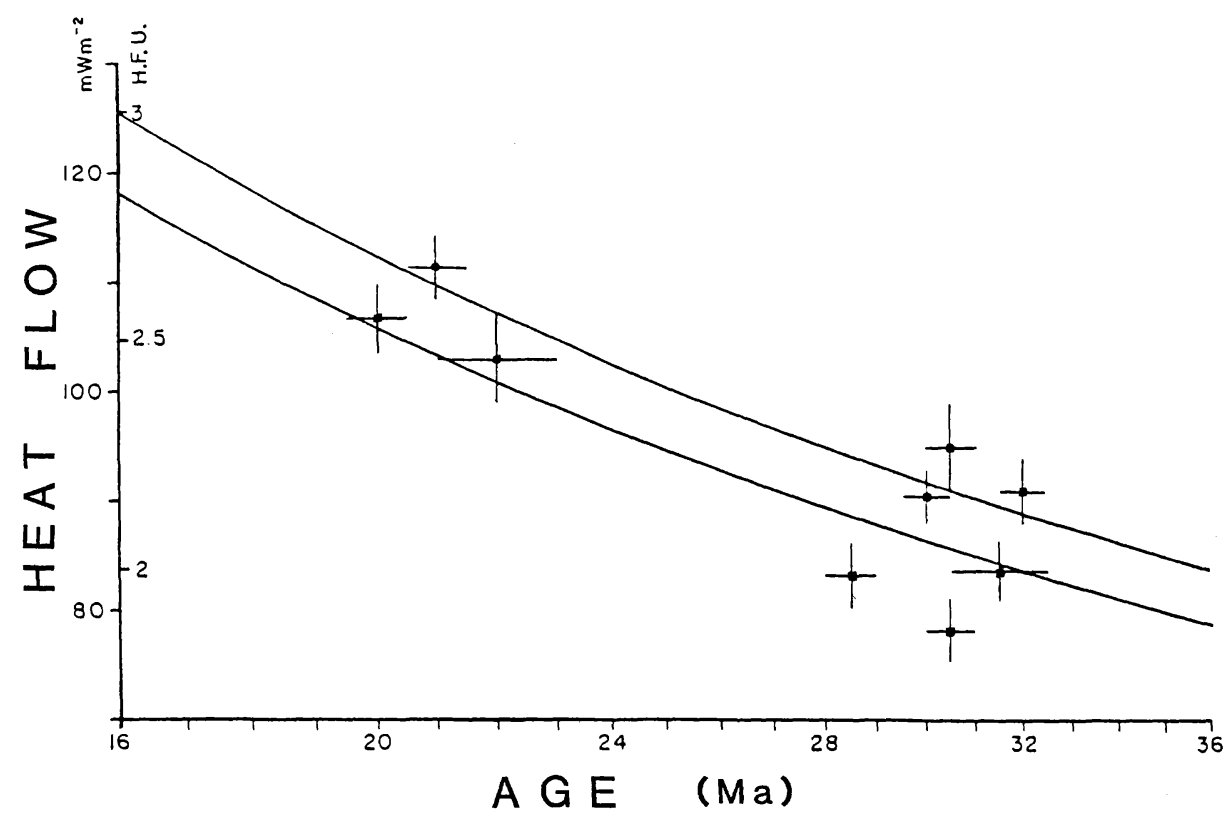

Fig. 9. Age-heat flow correlation of the South China Basin (TAYLOR and HAYES, 1983). Upper curve is based on DAvis and LISTER (1977) and lower one is from PARSONS and SCLATER (1977). 
Table 2. Average heat flow values of the basins in the Japan Sea.

\begin{tabular}{|c|c|c|c|c|c|c|c|c|}
\hline Japan & Basin & 120 & 117 & 116 & 113 & 112 & Average heat flow & \\
\hline \multirow[t]{13}{*}{67} & sites & 112 & 111 & 111 & 110 & 110 & of Japan Basin = & $95 \pm 12$ \\
\hline & & 110 & 109 & 109 & 108 & 107 & & \\
\hline & & 106 & 105 & 105 & 104 & 102 & & \\
\hline & & 102 & 102 & 101 & 100 & 99 & & \\
\hline & & 99 & 97 & 97 & 97 & 95 & & \\
\hline & & 95 & 94 & 94 & 93 & 92 & & \\
\hline & & 92 & 92 & 91 & 90 & 89 & & \\
\hline & & 89 & 89 & 89 & 89 & 89 & & \\
\hline & & 89 & 88 & 87 & 87 & 87 & & \\
\hline & & 87 & 87 & 86 & 86 & 85 & & \\
\hline & & 84 & 84 & 84 & 84 & 83 & & \\
\hline & & 83 & 82 & 80 & 79 & 78 & & \\
\hline & & 71 & 59 & & & & & \\
\hline Yamato & Basin & 145 & 111 & 108 & 107 & 107 & Average heat flow & \\
\hline \multirow[t]{5}{*}{26} & sites & 102 & 102 & 100 & 99 & 98 & of Yamato Basin = & $97 \pm 12$ \\
\hline & & 98 & 97 & 97 & 97 & 92 & & \\
\hline & & 91 & 90 & 90 & 90 & 89 & & \\
\hline & & 89 & 89 & 87 & 86 & 84 & & \\
\hline & & 82 & & & & & & \\
\hline Tsushima & Basin & 103 & 100 & 99 & 94 & 90 & Average heat flow & \\
\hline 6 & sites & 89 & & & & & of Tsushima Basin= & $96 \pm 6$ \\
\hline Tartary & Trough & 137 & 100 & 97 & 96 & 91 & Average heat flow & \\
\hline 6 & sites & 83 & & & & & of Tartary Trough= & $101 \pm 19$ \\
\hline Mogami & Trough & 67 & 59 & 58 & 54 & & Average heat flow & \\
\hline 4 & sites & & & & & & of Mogami Trough= & $59 \pm 6$ \\
\hline Oki & Trough & 87 & 83 & 79 & 72 & & Average heat flow & \\
\hline 4 & sites & & & & & & of Oki Trough $=$ & $80 \pm 6$ \\
\hline Kita-Yamato & Trough & 75 & 75 & & & & Average heat flow & \\
\hline 2 & sites & & & & & & of Kita-Yamato $T_{.=}$ & $75 \pm 0$ \\
\hline
\end{tabular}

The heat flow values are selected from Yoshil and YAMANO's (1983) heat flow digital data file according to the manner that the sites of the sediment thickness less than $300 \mathrm{~m}$ are rejected as well as sites less than $10 \mathrm{~km}$ from topographic highs.

sites in the Japan Sea. The sites were selected where the sediment thickness is greater than $300 \mathrm{~m}$ and where there are no seamounts within $10 \mathrm{~km}$, to eliminate the thermal disturbance by water circulation through porous basement rocks (Fig. 10). Values too low, less than $40 \mathrm{~mW} / \mathrm{m}^{2}$, were also eliminated in the Japan Basin. Seismic profiles on the ship's tracks of Fig. 2 and the sediment isopach map by IsHIWADA et al. (1984) were used to evaluate sediment thickness at the sites.

KOBAYASHI and NOMURA (1972) suggested that the heat flow value of the Japan Sea appears to be higher with an extent of $1.0 \mathrm{HFU}\left(41.8 \mathrm{~mW} / \mathrm{m}^{2}\right)$ as a result of iron sulfide oxidation. However, careful heat flow measurements in the Japan Basin and a heat flow measurement in a DSDP hole at Site 301 in the Japan Basin did not detect 


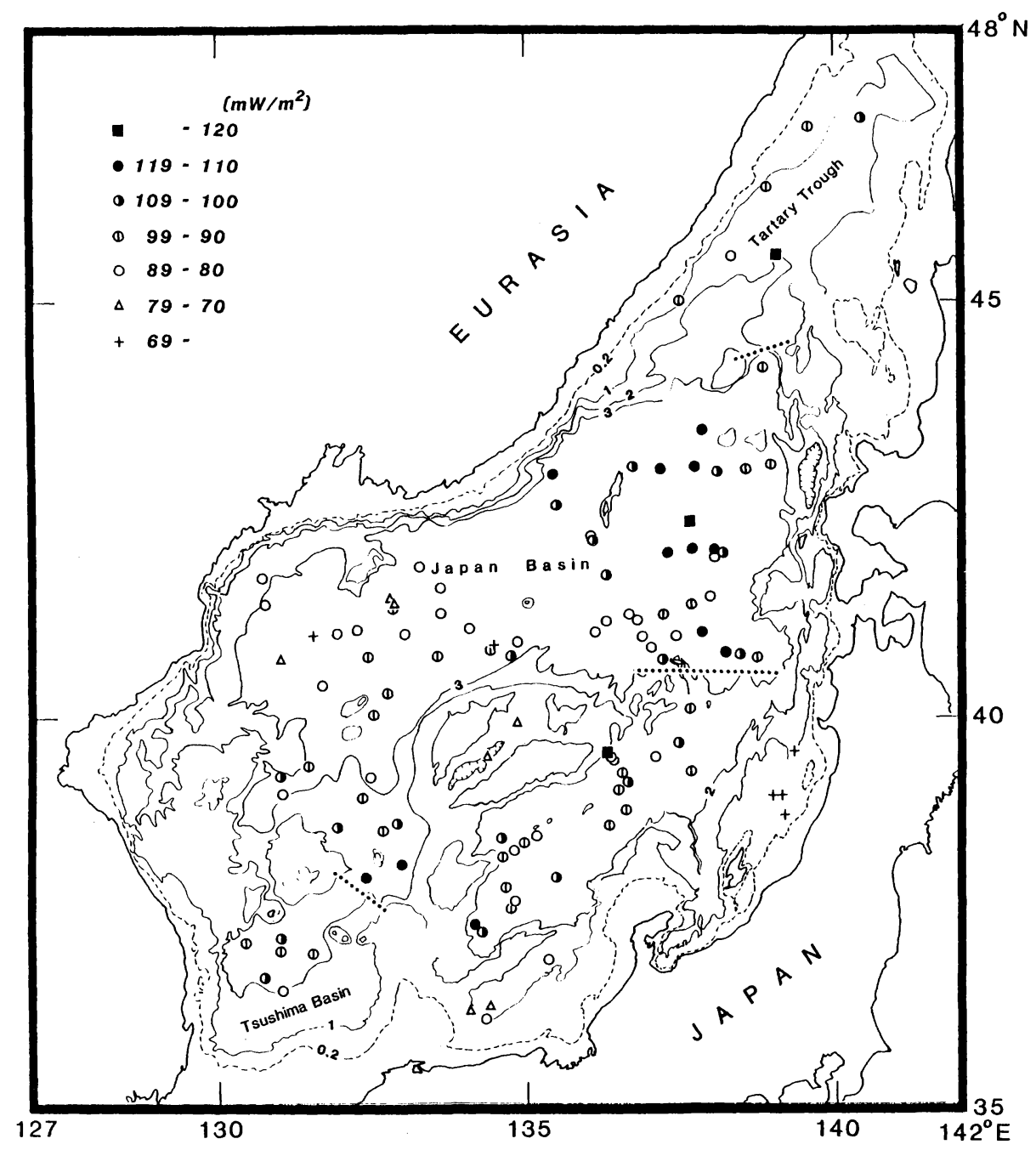

Fig. 10. Distribution of heat flow values in the basins of the Japan Sea. Plotted data are listed in Table 2. Dotted lines show boundaries of the basins for the averaging the heat flow value for each basin.

heat generation effect in the sedimentary layer (WATANABE et al., 1977). In this discussion, I disregard the secondary heat generation in the sediments, although there still remains the possibility of a little heat generation effect in the sediments of the Japan Sea as suggested by WATANABE et al. (1977).

The average heat flow value of the Japan Basin is $95 \mathrm{~mW} / \mathrm{m}^{2}$ corresponding to an age of 25 to $28 \mathrm{Ma}$. That of the Yamato Basin is $97 \mathrm{~mW} / \mathrm{m}^{2}$, corresponding to an age of 23 to $27 \mathrm{Ma}$. The average heat flow value of the Japan and Yamato Basins are very close. The average heat flow value, however, may not represent the average age of the basin. The data in Table 2 show a broad distribution as shown in Fig. 11. The broad distribution may depend on the variation of the age of the crusts in each basin, some 


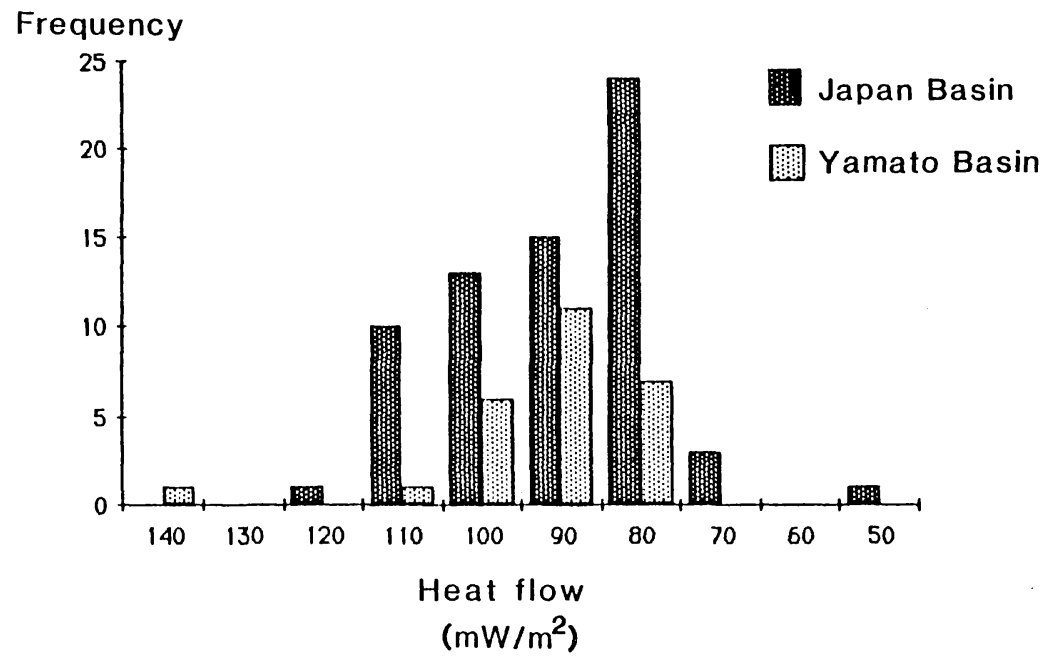

Fig. 11. Distribution of heat flow values in the Japan Basin and the Yamato Basin. The heat flow data are after YosHII and YAMANO's (1983) digital heat flow data file.

observational error, or local thermal disturbance by turbidites. However, it should be noted that $94 \%$ of the heat flow values of the Japan Basin and $96 \%$ of those of the Yamato Basin are included in the range between 80 and $120 \mathrm{~mW} / \mathrm{m}^{2}$. If we can adopt the range of 80 and $120 \mathrm{~mW} / \mathrm{m}^{2}$ as representative of the age range of the Japan Sea, the age of the Japan Sea is correlated to 39 to $15 \mathrm{Ma}$.

The sea bottom heat flow data generally appear less than the true terrestrial heat flow value because of the mass heat transfer by water circulation in the sediments and the basement rocks and rarely appear larger than the true terrestrial heat flow value. Therefore the discussion of the highest heat flow value may be valid. The highest heat flow value in the Japan Basin is $120 \mathrm{~mW} / \mathrm{m}^{2}$ which corresponds to an age from 15 to $18 \mathrm{Ma}$. The highest heat flow value in the Yamato Basin is $145 \mathrm{~mW} / \mathrm{m}^{2}$ which corresponds to an age from 10 to $12 \mathrm{Ma}$. An age from 10 to $12 \mathrm{Ma}$ for the Yamato Basin is concordant with the stratigraphic age estimation. The comparison of the highest heat flow values in the Japan and Yamato Basins reflects the younger age of the Yamato Basin. The sites of the highest heat flow for each basin are located in the central part of the Japan Basin and in the marginal part of the Yamato Basin (Fig. 10). The highest heat flow value may not correspond to the youngest age of the basin, but it is probable that the highest heat flow value suggests the youngest limit of the possible age of the basin if there are abundant measurements in the basin.

\section{Discussion}

Figure 12 summarizes the above discussion on the age of the Japan and Yamato Basins. Although the stratigraphic evaluation of the age of the Japan Basin is difficult to determine from the available data, the results of the age estimation based on basement depth and heat flow of the Japan Basin show good coincidence. 


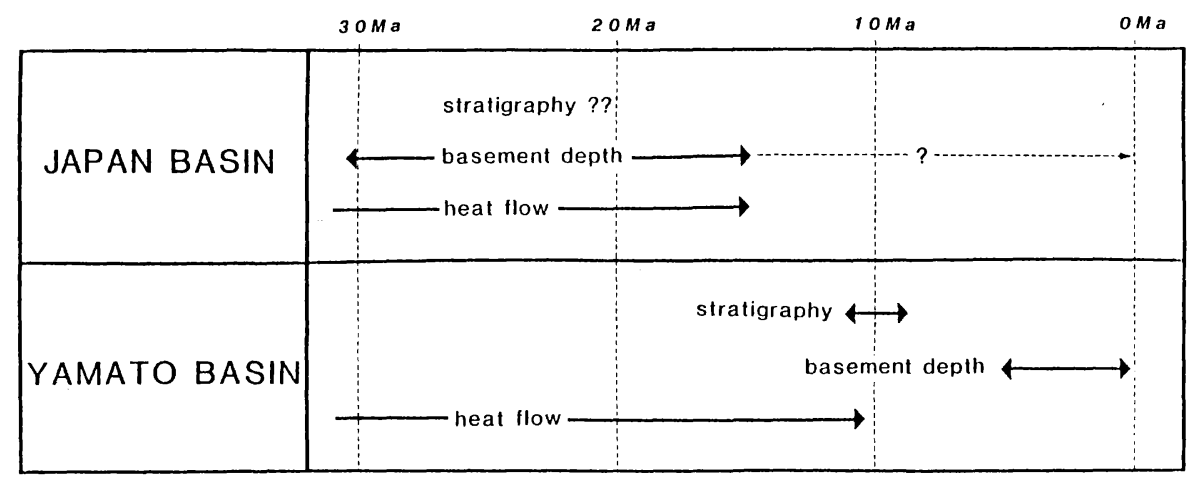

Fig. 12. Summary of the age estimation of the Japan Basin and the Yamato Basin on the basis of the three methods.

On the contrary, the results from the Yamato Basin show a large discrepancy among the three age estimation methods of stratigraphy, basement depth, and heat flow. Heat flow values suggest the age range from 30 or more to $10 \mathrm{Ma}$, the stratigraphy shows the age to be around $10 \mathrm{Ma}$, and the basement depth shows the age to be less than $6 \mathrm{Ma}$ through to $0 \mathrm{Ma}$. Earthquake and heat flow data, however, do not present any evidence which infers that the Yamato Basin is actively spreading. DSDP drilling results show the basement age to be older than $9 \mathrm{Ma}$. These observations indicate that the basement depth of the Yamato Basin is anomalously shallow. There are the following two possible causes for such a shallow basement.

(1) The acoustic basement is not identical with oceanic basaltic layer.

(2) The thickness of the crust is thicker than the normal oceanic crust and the depth becomes isostatically shallow.

Results of seismic refraction survey by LUDWIG et al. (1975) suggest that both of these causes are probable for the shallow basement of the Yamato Basin. According to their results, the acoustic basement of the Yamato Basin has a slower sonic velocity of 3.5 $\mathrm{km} / \mathrm{sec}$ compared to the normal oceanic basaltic layer which generally shows a velocity range from $4.5 \mathrm{~km} / \mathrm{sec}$ to $5.5 \mathrm{~km} / \mathrm{sec}$. The $3.5 \mathrm{~km} / \mathrm{sec}$ layer has a thickness of about $1 \mathrm{~km}$ and overlies a normal oceanic basaltic layer. The thickness of the crust is also thicker than that of the Japan Basin which is similar to normal oceanic crust. The crust of the Japan Basin is 6 to $7 \mathrm{~km}$ thick and that of the Yamato Basin is 11 to $12 \mathrm{~km}$. LUDWIG et al. (1975) explained that the $3.5 \mathrm{~km} / \mathrm{sec}$ layer is correlated to OligoMiocene volcaniclastics which are abundantly distributed on the Japan Sea side of the Japanese islands and are correlated as the "Green Tuff" horizon. The Yamato Basin with a thicker crust overlain by volcaniclastic layers may be formed under conditions different from the case of the Japan Basin (TAMAKI, 1985).

If a deeper true basement is the case of the Yamato Basin, the heat flow value of the basin is probably comparable with the true basement. The stratigraphic consideration of the age of the Yamato Basin is based only on the sedimentary layer. The $3.5 \mathrm{~km} / \mathrm{sec}$ layer intervenes between the sedimentary layer and the true basement. The rather young age from the stratigraphic consideration is reasonable if the $\mathbf{3 . 5}$ 
$\mathrm{km} / \mathrm{sec}$ layer is underlying the sedimentary layer. As a preliminary conclusion of an estimated age of the Yamato Basin, I present an age range of $30 \mathrm{Ma}$ or older to $15 \mathrm{Ma}$ which was deduced mainly from the distribution of heat flow values in Fig. 11. However, as a high heat value of $145 \mathrm{~mW} / \mathrm{m}^{2}$ is observed, there is a possibility that the younger age is extended to $10 \mathrm{Ma}$.

In the case of the Japan Basin, the age estimated from the basement depth shows rather good coincidence with the age estimated from heat flow values. The maximum basement depth observed is $5000 \mathrm{~m}$ after sediment loading correction in the Japan Basin. As the $3.5 \mathrm{~km} / \mathrm{sec}$ layer is also observed in the Japan Basin but not so commonly as in the Yamato Basin, the true basement depth may be a little deeper. I present an estimated age of $30 \mathrm{Ma}$ or older to $15 \mathrm{Ma}$ for the Japan Basin which is the same as that of the Yamato Basin. The Japan Basin also has a high heat flow value of $120 \mathrm{~mW} / \mathrm{m}^{2}$, suggesting that the age may be a few Ma younger.

The above estimated ages of the Japan Basin and the Yamato Basin have the same age range of $30 \mathrm{Ma}$ or older to $15 \mathrm{Ma}$. The results are inconsistent with two stage opening models of the Japan Sea (HILDE and WAGEMAN, 1973; KOBAYASHI, 1983) which insist that the Japan Basin is older than the Yamato Basin. If the opening ages of the both basins are different, a fracture zone structure is expected along the boundary between the both basins. Figure 13 shows a transition profile from the Japan Basin to the Yamato Basin. The basement gradually becomes shallower from the Japan Basin to the Yamato Basin without any fracture zone boundary. This feature suggests that the $3.5 \mathrm{~km} / \mathrm{sec}$ layer becomes thicker in the Yamato Basin. The conclusion of this paper is that the both basins opened concurrently with some time lags at the beginning and the ending stages.

\section{Conclusions}

Age estimation on the basis of three independent sets of data, sediment stratigraphy, basement depth, and heat flow value, suggests same age ranges of $30 \mathrm{Ma}$ or older to $15 \mathrm{Ma}$ for the Japan and the Yamato Basins. However, the estimated age range is not so confident as to constrain tectonic evolution of the Western Pacific. Further deep sea drillings and studies of magnetic anomaly lineations are necessary to fix the exact age of the Japan Sea. We expect the new Ocean Drilling Project and also new technology such as the three component magnetometer and deep-tow magnetometer for the identification of magnetic anomaly lineations.

Recent studies of paleomagnetism from the Southwest Japan arc (HAYASHIDA and ITO, 1984; OTOFUJI and MATSUDA, 1984) strongly suggest that the Southwest Japan arc rotated clockwise with an extent of $47^{\circ}$ and that the Japan Sea opened at 15 Ma with a duration of less than 1 million years (ОTOFUJI et al., 1985b). The suggested age of $15 \mathrm{Ma}$ conflicts with the age estimated in this paper. The maximum basement depth of the Japan Sea, $5000 \mathrm{~m}$, suggests the age to be around $30 \mathrm{Ma}$ and the average heat flow value of the Japan Sea, 95 to $97 \mathrm{~mW} / \mathrm{m}^{2}$, is much less than the expected heat flow value, 122 to $130 \mathrm{~mW} / \mathrm{m}^{2}$ for the age of $15 \mathrm{Ma}$. This is a serious contradiction for the study of the Japan Sea. However, this contradiction may be substantially related to a unique tectonic evolution of the Japan Sea. 


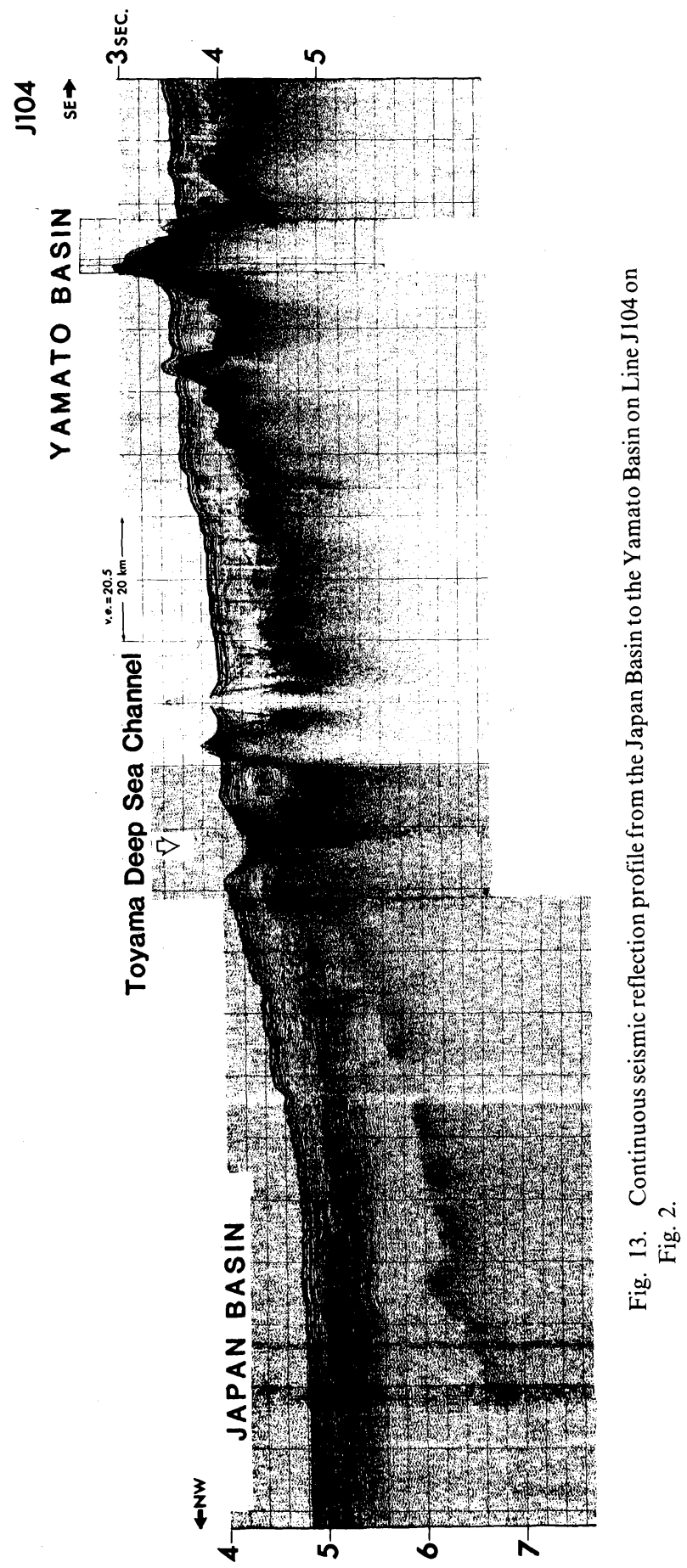


I present sincere thanks to $\mathrm{M}$. Yamano for his kind presentation of digital heat flow data file around Japan, and R. Takahashi, E. Honza, and T. Seno for their helpful discussion and suggestions.

\section{REFERENCES}

Abe, K. and H. Kanamori, Mantle structure beneath the Japan Sea as revealed by surface wave, Bull. Earthq. Res. Inst. Univ. Tokyo, 48, 1011-1021, 1970a.

ABE, K. and H. KanAmori, Upper mantle structure of the Philippine Sea, in Island Arc and Ocean, edited by M. Hoshino and H. Aoki, pp. 85-91, Tokai Univ. Press, Tokyo, 1970 b.

Anderson, R. N., 1980 update of heat flow in the east and southeast Asian seas, in The Tectonics and Geologic Evolution of Asian Seas and Islands, edited by D. E. Hayes, Geophys. Monogr. Ser., Vol. 23, pp. 319-326, AGU, Washington, D. C., 1980.

Crough, S. T., The correction for sediment loading on the seafloor, J. Geophys. Res., 88, 6449-6454, 1983.

Davis, E. E. and C. R. B. LISTER, Heat flow measured over the Juan de Fuca Ridge: Evidence for widespread hydrothermal circulation in a highly heat transportive crust, J. Geophys. Res., 82, 4845-4860, 1977.

Gnibidenko, H., The tectonics of the Japan Sea, Marine Geol., 32, 71-87, 1979.

Hayashida, A. and Y. ITo, Paleoposition of Southwest Japan at $16 \mathrm{Ma}$; implication from paleomagnetism of the Miocene Ichishi Group, Earth Planet. Sci. Lett., 68, 335-342, 1984.

HAYES, D. E., Global studies of ocean crustal depth-age relationships, EOS Trans. AGU, 64, 760, 1983.

Hilde, T. W. C. and J. M. Wageman, Structure and origin of the Japan Sea, in The Western Pacific, edited by P. J. Coleman, pp. 415-434, Univ. Western Australia Press, 1973.

Honza, E. (ed.), Geological investigation of the Japan Sea. Geol. Surv. Japan Cruise Rept., 13, 99, 1979.

Hussong, D. M. and S. UyedA, Tectonic process and the history of the Mariana Arc: a synthesis of the results of Deep Sea Drilling Project Leg 60, in Initial Reports of the Deep Sea Drilling Project, edited by D. M. Hussong and S. Uyeda, et al., Vol. 60, pp. 909-929, U. S. Government Printing Office, Washington, D. C., 1982.

ISEZAKI, N. and S. UYEDA, Geomagnetic anomaly pattern of the Japan Sea, Marine Geophys. Res., 2, 51-59, 1973.

Ishiwada, Y., E. Honza, and K. Tamaki, Sedimentary Basins of the Japan Sea, Proc. 27th Int. Geol. Congr., 23, 43-65, 1984.

KARIG, D. E. and J. C. M. Ingle Jr. (eds.), Initial Reports of the Deep Sea Drilling Project, Vol. 31, p. 927, U. S. Government Printing Office, Washington, D. C., 1975.

Klein, G. deV. and K. Kobayashi, Geological summary of the north Philippine Sea, based on Deep Sea Drilling Project Leg 58 results, in Initial Reports of the Deep Sea Drilling Project, edited by G. deV. Klein and K. Kobayashi, et al., Vol. 58, pp. 951-961, U. S. Government Printing Office, Washington, D. C., 1980.

Kobayashi, K., Spreading of the Sea of Japan and drift of Japanese Island Arc: A synthesis and speculation, in Island Arcs, Marginal Seas, and Kuroko Deposits, Mining Geologists Special Issue, edited by E. Horikoshi, Vol. 11, pp. 23-36, The Society of Mining Geologists of Japan, Tokyo, 1983 (in Japanese with English abstract).

Kobayashi, K., Subsidence of the Shikoku back-arc basin, Tectonophys., 102, 105-117, 1984.

Kobayashi, K. and M. Nomura, Iron sulfide in the sediments cores from the Sea of Japan and their geophysical implications, Earth Planet. Sci. Lett., 16, 200-206, 1972.

Korzumi, I., The geological history of the Sea of Japan-based upon sediments and microfossils-, Nihonkai (Japan Sea), 10, 69-90, 1979 (in Japanese).

Kono, Y. and M. Amano, Thickening plate model with sedimentation, J. Seismol. Soc. Japan, 30, 163-178, 1977 (in Japanese with English Abstract).

Ludwig, W. L., S. Murauchi, and R. E. Houtz, Sediments and structure of the Japan Sea, Geol. Soc. Am. Bull., 86, 651-664, 1975.

Otofuji, Y. and T. Matsuda, Timing of rotational motion of Southwest Japan inferred from paleomagnetism, Earth Planet. Sci. Lett., 70, 373-382, 1984.

Otofuji, Y., T. Matsuda, and S. Nohda, Opening mode of the Japan Sea inferred from the paleomagnetism of the Japan Arc, Nature, 317, 603-604, 1985a. 
Otofuji, Y., A. HaYAshida, and M. ToRII, When was the Japan Sea opened?: paleomagnetic evidence for Southwest Japan, in Formation of Active Ocean Margins, edited by N. Nasu, I. Kushiro, K. Kobayashi, and H. Kagami, pp. 551-566, Terrapub, Tokyo, 1985b.

Parsons, B. and J. G. Sclater, An analysis of the variation of ocean floor bathymetry and heat flow with age, J. Geophys. Res., 82, 803-827, 1977.

Sclater, J. G., D. E. Karig, L. A. Lawver, and K. Louden, Heat flow, depth, and crustal thickness of the marginal basins of the South Philippine Sea, J. Geophys. Res., 81, 309-318, 1976.

ShimazU, M., "Green Tuff” in the core from DSDP Leg 31 Site 302: Kita-Yamato tai, J. Geol. Soc. Japan, 85, 655-656, 1979 (in Japanese).

TAMAKI, K., Two modes of back-arc spreading, Geology, 13, 475-478, 1985.

Tamaki, K., E. Honza, M. Yuasa, K. Nishimura, and F. Murakami, Geological map of the central Japan Sea, Marine Geol. Map Ser., 15, 1981.

TAYlor, B. and D. E. Hayes, Origin and history of the South China Sea Basin, in The Tectonics and Geologic Evolution of Southeast Asian Seas and Islands Part 2, edited by D. E. Hayes, Geophys. Monogr. Ser., Vol. 27, pp. 23-56, AGU, Washington, D. C. 1983.

von Herzen, R. P. and S. UyedA, Heat flow through the eastern Pacific floor, J. Geophys. Res., 68, 42194250, 1963.

Watanabe, T., M. G. Langtheth, and R. N. Anderson, Heat flow in back-arc basins of the Western Pacific, in Island Arc. Deep Sea Trenches and Back-arc Basins, edited by M. Talwani and W. C. Pitman III, Maurice Ewing Ser., Vol. 1, pp. 137-161, AGU, Washington, D. C., 1977.

Yoshi, T. and M. Yamano, Digital heat flow data file around Japanese Islands, 1983.

YoshiI, T., Y. Kono, and K. ITo, Thickning of the oceanic lithosphere, in The Geophysics of the Pacific Ocean Basin and its Margins, edited by G. H. Sutton et al., Geophys. Monogr. Ser., Vol. 19, pp. 423-430, AGU, Washington, D. C., 1976. 